\title{
CAUSES AND METHODS OF APPLYING BUILDING PROTECTION FROM THE IMPACT OF RAIL-TRANSPORT
}

\author{
Magdalena Filipiak $^{1^{*}}$, Jan Targosz ${ }^{2}$ \\ ${ }^{1}$ WIP ProjektSp. z o.o. Warszawa, Poland, email: magdalena.filipiak@gmail.com \\ ${ }^{2}$ Stanislaw Staszic AGH University of Science and Technology, Department of Robotics and Mechatronics, Al. Mickiewicza 30, 30-059 Kraków, \\ e-mail: jantargosz@interia.pl \\ *Corresponding author
}

Reviewed positively: 12.08 .2019

Information about quoting an article:

Filipiak M., Targosz J. (2019). Causes and methods of applying building protection from the impact of rail-transport. Journal of civil engineering and transport. 1(1), 27-37. DOI: 10.24136/tren.2019.003

Abstract - The paper presents an attempt to unify the issue of acoustic vibro-insulation used in the design of buildings and its impact on the building structure based on a calculation example. While the methodology of selection and methods of acoustic insulation of buildings from airborne traffic noise, as well as methods of limiting the structure vibrations to acceptable levels are widely recognised and applied, there is nogenerally accepted methodology of limiting the secondary noise that can be generated in buildings as a result of vibrations transmitted through the ground to the foundations and structure of the building (so-called ground-borne noise or re-radiated noise).

Key words - vibrations, vibro-insulation, sound insulation, material-to-material vibrations

\section{INTRODUCTION}

As cities develop, the demand for fast and collision-free transport infrastructure in cities increases. Due to urban constraints, especially in the centres of large urban agglomerations, above-ground and underground rail transport (trams, high-speed urban railways or underground) is becoming the preferred means of transport. The limited available areas for development also cause that new buildings are increasingly being erected in the vicinity of existing or planned routes of railways. At the same time, the increasing scope of knowledge on the harmful effects of vibrations resulting in noise emission results in stricter standards concerning their limitations, resulting both from the regulations and from the expectations of users and residents of buildings. While the methodology of selection and methods of acoustic insulation of buildings from airborne traffic noise, as well as methods of limiting the structure vibrations to acceptable levels are widely recognised and applied, there is no generally accepted methodology of limiting the secondary noise, which can be generated in buildings as a result of vibrations transmitted through the ground to the foundations and structure of the building (so-called groundborne noise or re-radiated noise). The paper presents an attempt to standardize the vibration, and sound insulation that can be used in the design of buildings, and its impact on the structure in terms of acoustic comfort in their rooms.

\section{SOUND SOURCES IN BUILDINGS AND STANDARDS}

Acoustic processes are physical processes in which particles of a compressible medium vibrate in relation to the equilibrium position. Vibrating elementary masses influence the adjacent masses, thus propagating elastic disturbance in the medium called waves. Sounds are understood as audible acoustic vibrations, which are positioned in a frequency range from about $16 \mathrm{~Hz}$ to about $20 \mathrm{~Hz}$ [1]. Acoustic vibrations may propagate in all compressible media, in solids, liquids and gases. The source of sound in buildings are primarily acoustic vibrations propagating in the air, but the source can also be vibrations transmitted through the ground, as shown in Figure 1.

As far as rail transport is concerned, vibrations caused by moving vehicles are transferred through the ground to the foundations of the building, and then propagated through its foundation structure to residential or commercial rooms located on higher floors, which may cause the formation of so-called material noises. This effect can occur with ground vibrations in the frequency range of approx. $30 \mathrm{~Hz}$ to about $200 \mathrm{~Hz}$, especially in case of rail transport in tunnels, where complex vibration isolation is not usually used. As the availability and use of material vibration isolation increases, this type of material-borne noise is also more and more often felt in facilities located close to ground rail traction [3-4]. 
Noise is commonly defined not only as sounds harmful to health, but also all sounds that are unpleasant undesirable, hindering or preventing work or rest [4]. Noise can, therefore, have a negative impact both on the hearing organ or internal organs of a person, as well as on his or her psyche. It is generally accepted [3] that noise below $35 \mathrm{~dB}(\mathrm{~A})$ is not harmful to health, but it can be annoying and thus interfere with work that requires concentration, or with rest. Noise levels of $35 \mathrm{~dB}(\mathrm{~A})$ to $70 \mathrm{~dB}(\mathrm{~A})$ can affect nervous fatigue, reduce vision sensitivity and speech intelligibility, and seriously hinder sleep and rest. Noise at higher levels can be harmful to health or even cause a number of illnesses.

According to the law applicable in Poland, the permissible noise levels in the environment caused by particular groups of noise sources - with the exception of noise caused by take-offs, landings and flights of aircraft and power lines and outside the " $\mathrm{A}$ " protection zones of health resorts and hospitals outside the city - range from 40 to $60 \mathrm{~dB}$ at night (LaeqN) and from 50 to $68 \mathrm{~dB}$ during the day (LaeqD), depending on the type of terrain and the type of noise source [5-6].

The Regulation of the Minister of Infrastructure on the technical conditions to be met by buildings and their location [6] states in par. 11. item 1 that "a building with rooms designated for human occupancy should be erected outside the range of risks and nuisances specified in separate regulations, but the erection of buildings within this range is permitted provided that technical measures to reduce nuisance below the level specified in these regulations are applied (...)". In the same paragraph in item 2, the Regulation mentions, among others, noise and vibration as one of these nuisances.

\section{MethodS LIMITING MATERIAL SOUNDS IN BUILDINGS}

The most common way to reduce the noise level from rail transport is to use an appropriate substructure taking into account the vibro-insulation, which is primarily to provide protection against vibrations transmitted through the ground to buildings in accordance with the requirements specified in the standards [11-12], and to reduce the level of emitted sound to the environment. However, the structure of vibration isolation systems currently used in renovated tracks, especially in city centres, not always meet the requirement to limit the dynamic impact on the environment, and sometimes even worsen the existing environmental and riverside conditions [13]. Also, as theoretical analyses presented in the literature of the subject, and the results of measurements of continuous vibration monitoring systems in the Warsaw Metro indicate, the level of vibrations emitted to the environment and neighbouring buildings also significantly depends on the operating conditions, e.g. on the condition of rails or rolling stock, and even on the passenger occupancy ratio in rolling stock vehicles [14], and therefore, it may also change in time. Due to the close association of the process of "ideal operation of the device" with vibrations disturbing its movement, it is necessary to fathom the whole dynamic process implemented by a specific mechanical object, so that it is possible to effectively reduce the disturbances without interfering with its proper, working functions.

Some causes of vibration can be eliminated in a relatively easy way. These include, for example, isolation of device from kinematic excitation, transmitted by the environment, and isolation of vibration sources in the device itself, so that vibrations in a certain frequency range of $0 \div 50[\mathrm{~Hz}]$, are propagated only in a limited space and are not transmitted to the surrounding environment, which is the basic issue of vibration isolation.

\section{THEORETIC BASIS FOR VIBRATION ISOLATION}

In theoretical studies concerning the minimization of vibrations, it is necessary to distinguish the isolation of the environment from dynamic interactions at low frequencies $\mathrm{f}_{0}<50[\mathrm{~Hz}]$, and the isolation of structural elements due to the

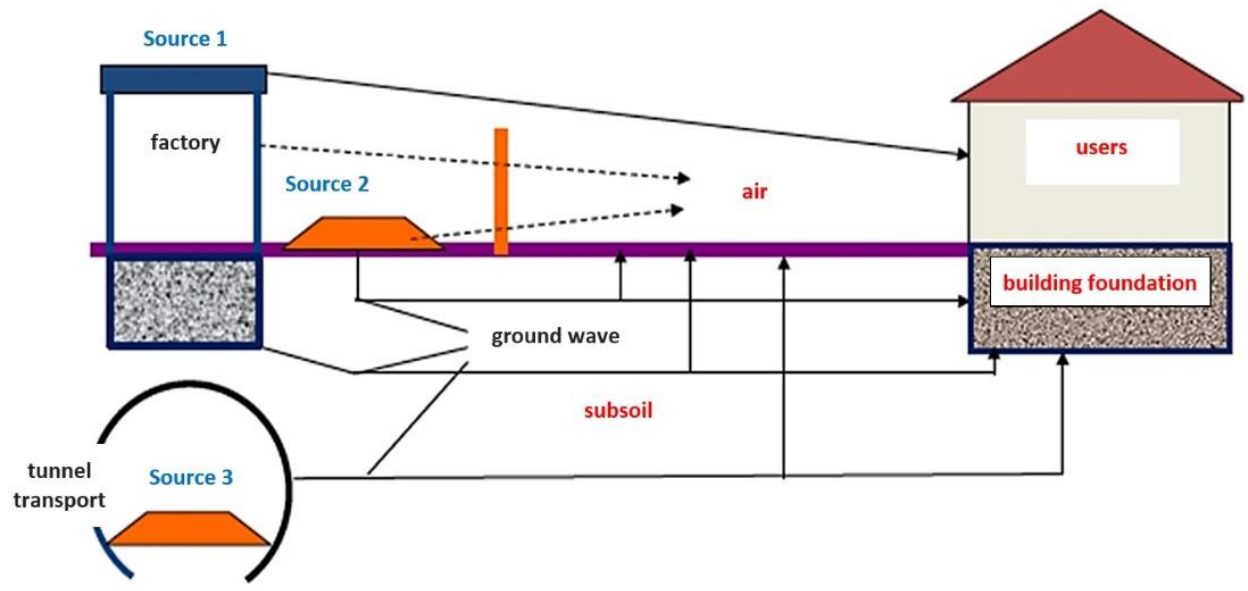

Fig. 1. Diagram of propagation of noise and vibrations in a residential building from traffic, internal sources and from an industrial plant 
high frequencies of material vibrations, the so-called sound insulation. Vibration insulation is divided into force and displacement insulation. The first one is aimed at limiting the dynamic effects on the ground, the second one concerns the reduction of vibrations transferred from the ground to the object, which is the subject of this task.

Such issues can be described mathematically as a process of optimization with some restrictions. Targe functions, in this process, are defined depending on the type of considered device, e.g. as a minimum of changes in vibration amplitude resulting from the technological process for a specific frequency, minimum of energy demand minimum of dynamic impact on the environment for a specific frequency of extortion. These restrictions in the process of designing transport roads [3], road-rail crossings, railway crossings, rail vehicle substructures, the environment of these roads result from structura restrictions including: arrangement of elastic-damping elements, permissible static deflections, arrangement of masses, technological possibilities of realization of elastic drive components at desired parameters, as well as from external restrictions, e.g. dynamic interactions with the environment. The selection of parameters for elastic elements should be carried out in a modern approach based on an analysis of the vibrating model together with equations that take into account the dynamics of transport equipment. For transport roads, substructures and other objects in general, a model with six degrees of freedom is adopted, treating these systems as rigid solids supported on massless elastic-damping elements. The effect of such an approach is the occurrence of at least six natural frequencie in the considered system. If in the analyzed system there is a frequency of excitation equal to one of the frequencies of natural vibrations, then the phenomenon of resonance will occur. The occurrence of the resonance phenomenon may cause in extreme cases the rupture of elastic bonds. In order to prevent this during the design process, a dynamic analysis of forced vibrations should be carried out to assess the correctness of the selection of elastic-mass elements. Introducing a system of generalised coordinates of $\mathrm{si}_{\mathrm{i}}$ and corresponding generalised forces $\mathrm{P}_{\mathrm{i}}$, where $\mathrm{i}=1,2, \ldots 6$, using the Lagrange II equation of type, we obtain a dynamic movement equation:

$$
\beta_{\mathrm{i}} \ddot{\mathrm{s}}_{\mathrm{i}}+\mathrm{h}_{\mathrm{i}} \dot{\mathrm{s}}_{\mathrm{i}}+\mathrm{k}_{\mathrm{i}} \mathrm{s}_{\mathrm{i}}=\mathrm{P}_{\mathrm{i}}(\mathrm{t})
$$

where: $\beta_{i}, h_{i}, k_{i}$ coefficient of mass, damping and flexibility or in a matrix form, without damping, in a form of:

$$
\mathrm{Bs}+\mathrm{K} \ddot{\mathrm{s}}=\mathrm{P}(\mathrm{t})
$$

where:

B - inertia matrix,

$\mathrm{K}$ - elasticity matrix

$\mathrm{P}(\mathrm{t})$ - external extortion,

Determination of stiffness coefficients for the vibration isolation system allows the determination of natural frequencies of the system using the solution of the natural problem defined by the following dependency:

$$
\left(K-\omega^{2} B\right) X=0
$$

Equation (3) has to be transformed to the standard form.
To this end, it is required to multiply the above equation by an inverse matrix of inertia $\mathbf{B}^{-1}$ and then the following can be achieved:

$$
\left(A-\omega^{2} l\right) X=0
$$

where:

$A=B^{-1} K$,

$\mathbf{I}=\mathbf{B}^{-1} \mathbf{B}-$ unitary matrix

In this way, a specific problem can be solved by means of known numerical calculations, which are generally available in many packages of mathematical program algorithms. The derived movement equations enable also the analysis of forced vibrations of the system. The classic approach to designing a vibration isolation system consists in reducing the dynamics of the system to a model with one one degree of freedom and the arrangement of elastic and damping elements so that the movement of the system model occurs along one of the main central axes of inertia. To achieve this, the following condition must be met: the arrangement of the elastic elements under the vibration-insulated system must ensure that the centre of their stiffness coincides with the centre of vibration-insulated system mass. This requires, in particular, that the elastic elements be suitably located in relation to the main central axes of the inertia. This approach makes it possible to clearly define the amplitude-frequency characteristics and ranges of vibration isolation characteristics of various types of vibration-insulated objects.

Then, the condition for the proper functioning of the vibration isolation system is that it meets this condition:

$$
\frac{\omega}{\omega_{0}} \geq \sqrt{2}
$$

where:

$\omega$ - frequency of forced trigger,

$\omega_{0}$ - frequency of natural vibration,

$\omega_{0}=\sqrt{\frac{k}{m}}$,

$\mathrm{k}$ - stiffness,

$\mathrm{m}$ - mass.

It is not always possible to meet condition (1), because the mechanical system, vibro-isolated with the use of massstructured elements, may be exposed to multiple resonance. Therefore, it is necessary to introduce the concept of the vibro-isolation condition, which is most generally based on the fact that the vibro-isolation system, when changing the frequency of trigger from the ground, provides for a limited range of changes in vibration amplitude, while at the same time meeting the vibroisolation condition, described on a limited set of natural vibration frequencies, which excludes the possibility of internal resonances related to wave effects. On this basis, we can implement a modified vibration isolation condition in the following form:

$$
\mathrm{f}_{\mathrm{oi}}<\mathrm{f}_{\mathrm{w}}<\mathrm{f}_{\mathrm{oi}+1}, \mathrm{i}=1,2, \ldots \mathrm{n}
$$

The above condition means that the physical parameters of a system with multi-degree freedom must be selected so that the triggering frequency is within a range 
limited by two consecutive natural frequencies. Where the mass of the vibro-isolating element is significant, or where the geometric dimensions of the vibration isolation system components are similar to a belt or sheet, modelling the vibration isolation system as a discrete system entails certain risks. The most important of these is the wave phenomenon of elastic elements, because in such a case, one should not assume that these elements are massless. Internal resonances (wave effects) may occur in this type of element, which may cause the vibration isolation effect to be insignificant, i.e. to limit dynamic interactions with the environment. In order to prevent such a possibility, it is necessary to determine the natural frequency of the vibroisolating system based on the consideration of this system as a continuous or discrete-continuous model.

\section{THEORETICAL BASE FOR SOUND INSULATION}

Sound insulation is understood as the reduction of vibrations of particles in an elastic environment with wavy distribution. From the mechanical point of view, these are material and acoustic vibrations within the frequency range of $\mathrm{f}=100-5000 \mathrm{~Hz}$. The models are mechanical systems with a continuous structure and corresponding mathematical description - partial differential equations. Mathematical vibrations of transport route construction elements can be determined by their admittance:

$$
\frac{1}{Z(\omega)}=\frac{V(\omega)}{F(\omega)}
$$

where:

$Z(\omega)$ - impedance,

$\mathrm{V}(\omega)$ - amplitude of the vibration velocity,

$F(\omega)$ - amplitude of the driving force.

Input admittance defines the velocity $\mathrm{V}\left(\mathrm{x}_{0}\right)$ at the point of application of the driving force, but also with a good approximation of the mean velocity $V_{m}=\sqrt{V^{2}}$, which is forced on the vibrating element of the structure. Using the knowledge that the spectrum of the driving force covers relatively densely the amplitudes of the spectrum corresponding to the speed $V_{m}$, we can use the dependence in the following form:

$$
V_{m}^{2}=\frac{1}{m \sqrt{B}}
$$

where:

$B$ - stiffness of the slab of the soundproofing element,

$m$ - mass of the soundproofing element.

The above relation shows that material vibrations are the lower the heavier and stiffer is the structure of the sound-insulating element. Material vibrations generate sounds by radiating them through outer surfaces of the structure, so it is important to reduce the effect of stiffness and mass on flexural sound pressure levels by using suitable flexible liners having highly insulating properties and absorbing audible frequencies.

\section{PRACTICAL METHOdS OF VIBRATION ISOLATION AND} SOUNDPROOFING

Reducing vibrations from rail transport to the values required by the standards does not, however, mean elimination of noise from material sounds occurring in rooms of buildings, because the standard [11] takes into account, apart from the type of vibrations, first of all the basic structural features of the building, such as the condition of the building, materials and type of the building structure or the type of foundation and method of foundation, having an impact on the dynamic response of the building. In many cases, it allows the influence of vibrations transmitted by the subsoil on the building to be disregarded when designing the building. The standard [11] does not in any way indicate the relation between the vibrations of a building and the material sounds it triggers in rooms. There are also no studies on this subject in the available national literature. In some cases, where the insulation from material sounds is necessary, e.g. in measurement rooms, acoustic laboratories or radio stations, a solution consisting in complete isolation of such a room from the rest of the building and its foundation on separate foundations or vibro-insulators, as shown in Figure 2, has usually been applied so far.
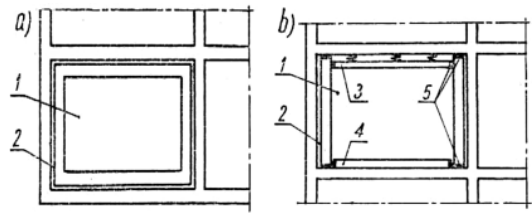

c)

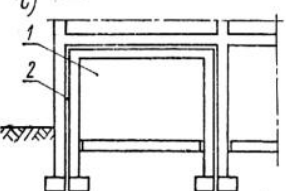

1 - rooms requiring anti-vibration insulation, 2 - expansion joint, 3 - suspended ceiling panel, 4 - "floating floor", 5 - anti-vibration pads Fig. 2. Diagrams of insulation of rooms in the building: a) in the ground floor, b) cross-section on the first floor c) cross-section on the ground floor [2]

While the solution shown can be effective in case of individual rooms, in practice it cannot be used in case of e.g. the entire multi-family residential or office building, mainly due to the limitations in the available space, as well as a significant increase in the cost of additional structures. Therefore, it is increasingly common to introduce vibration isolation between structural isolation, e.g. at the level of their foundation or on columns supporting the floor, by substituting elastomer pads or spring-loaded vibroinsulators as shown in Figures 3 and 4 . Implementing the vibro-insulation above the foundation level causes a number of inconveniences, as it is often associated with the need to introduce additional column heads or brackets on the walls, increasing the dimensions of these elements, unusual fire protection requirements, and taking into account additional insulation when designing the installation ducting arrangement. However, such a solution is more beneficial from the point of view of safety of the building during its use, because easy access to the elements of the vibration insulation allows to control their technical condition on an ongoing basis, and allows a reduction in the costs of their 
possible replacement.

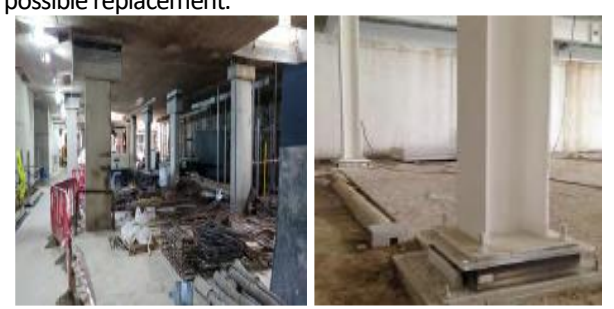

Fig. 3. Examples of the use of elastomer pads as vibration isolation for the structural elements [15]

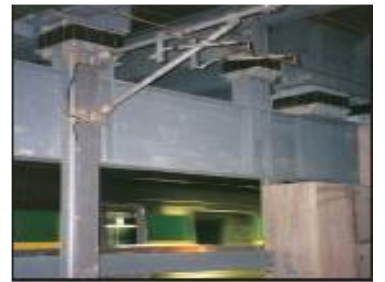

Fig. 4. Example of application of spring vibro-insulator on structural columns [16]

The choice of appropriate vibration insulation in a building depends on a number of factors - first of all on its required effectiveness, i.e. the frequency of vibrations transmitted by the ground and the natural vibration frequency of vibration insulation systems, but also on such parameters as e.g. load and deflection in the structure, the impact of applying vibration insulation on architectura solutions or its costs. If the required natural vibration frequency of vibro-isolation is higher than $5.5 \mathrm{~Hz}$, then the use of elastomer pads is a more economic solution; at lower frequencies it will be necessary to use spring vibro-insulators [16]

\section{Determination OF MATERIAL SOUND LEVEL}

When designing buildings in the vicinity of vibration sources, the impact of these vibrations on the building and its occupants should be determined at the earliest possible stage, e.g. during the preparation of the Design Information Sheet. Although there are no clear legal requirements in this respect, it seems appropriate that also at this stage, the acoustician involved in the preparation of the report should determine the expected level of material sounds in the building and determine whether it is necessary to minimize it.

The most common methods of determining the level of

material sound transmitted through the ground are [17]:

- theoretical/(semi-)analytical method

- in-situ tests/field measurements using a Modular Prediction Approaches

- empirical predictions/model of Direct Measurements Prediction Model DMPM

- Numerical methods.

The choice of the method for determining the level of sound transmitted by the ground depends on many factors, including the type of vibration source, the type of soil which transmits the vibrations, but also on the accuracy of the predictions obtained at a specific stage. For example, in the initial phases of the project, the results obtained on the basis of a fast but conservative, semi-analytical method, e.g. the "pipe-in-pipe" method developed for the needs of linear sources of ground vibrations from subterranean rail transport [16], may be sufficient. If the level of material sound determined by the acoustician exceeds the acceptable values determined by the investor or architect, the available options for minimizing it should be considered, e.g. by considering vibration isolation in the building structure. Such a decision should be taken as early as possible, as the introduction of such protection has a significant impact on both the design solutions in the building for all industries, as well as on investment costs. However, the costs of using vibro-insulation at the design stage will be incomparably lower than in case of operating buildings, for which it may not be feasible in practice to provide adequate vibration isolation from the sound of materials carried by the ground.

The methodology of considering vibro-insulation in the building structure design is an iterative, multi-stage process requiring multi-discipline coordination between the constructor, architect, acoustician, installation designers and investor. Particular attention should be paid to the impact of the implementation of such insulation on the stiffness and operation of the building structure. The consideration of vibration insulation in the building should be carried out in the following way [15-16]

a) due to architectural requirements (e.g. location of rooms to be isolated from noise, available space, possible need for additional heads on columns, etc.), the architect together with the constructor and acoustician determine the most appropriate place for introducing vibro-isolation into the building structure;

b) the acoustician together with the constructor and the investor determine the appropriate percentage of variable loads, which should be taken into account when selecting vibro-isolation in order to achieve its effectiveness determined by the acoustician; for example, for concert halls and theatres, only constant loads should be taken into account in calculations, for office or residential buildings of high standard - constant loads and $10 \div 20 \%$ of variable loads, for office and residential buildings of medium or low class - constant loads and $30 \div 40 \%$ of variable loads [15];

c) the structure designer performs static calculations with predetermined straight hinges in the points of support, and determines vertical forces from constant and variable loads acting on vibration isolation in the points of its application;

d) the vibration acoustics specialist selects the vibroinsulation on the basis of given forces and the agreed load combination, stating the stiffness of the vibro-insulation at individual points of its application;

e) the building contractor applies into the design model a spring support with the stiffness given by the vibration acoustics specialist at the site of the previously introduced rigid hinges and, after the calculation, recalculates the vertical forces as in point (c);

f) the procedure specified in points $\mathrm{c} \div$ e should be repeated until the results between the iterations differ by more 
than $10 \%$;

g) after the final design of the vibration isolation from vertical loads, the designer shall also include horizontal loads, e.g. from wind, in the design model and shall determine the necessity and method of horizontal stiffening of those members whose static working pattern has been changed by the introduction of vibration-regulation (elastic hinges), which may increase the dimensions of the structural components on which the washers are laid;

h) changes resulting from the application of vibration isolation must be adequately taken into account and coordinated with the participation of a vibro-acoustics specialist in the design of all industries, so that any architectural finish and the way in which equipment and installations are fitted and installed do not affect the effectiveness of the designed building vibration isolation system.

\section{Calculation example based on AN ADOPTED BUILDING MODEL}

The structure of the building accepted for consideration is a residential multi-family building with four above-ground storeys and one underground storey. It is a column-and-slab structure in which the main stiffening element are the core walls routed from the foundation level to the highest ceiling slab. The building is erected directly through a foundation slab on the ground. All the structural elements are designed to be made of reinforced concrete.

Sound insulation in the form of elastomer pads will be implemented on underground storey pillars under the ground floor slab and in the place of foundation of the main building core. The spatial model of the building structure is shown in Figure 5.

Static calculations were performed using MES Autodesk $^{\circledR}$ Robot $^{\mathrm{TM}}$ Structural Analysis Professional 2016. The calculations assumed the following loads:
- Constant loads - own weight (assumed in the program automatically on the basis of the set geometry) and surface load with finishing layers of $2.5 \mathrm{kN} / \mathrm{m}^{2}$ on intermediate floors and $2.0 \mathrm{kN} / \mathrm{m}^{2}$ on the roof

- variable usable loads: $2.0 \mathrm{kN} / \mathrm{m}^{2}$ on intermediate floors and $0.4 \mathrm{kN} / \mathrm{m}^{2}$ on the roof and snow load of $0.72 \mathrm{kN} / \mathrm{m}^{2}$ on the roof.

At this stage, horizontal loads, e.g. wind loads or geometric imperfections (second order effects) were not taken into account [17]

The basic calculation model with assumed dimensions of structural elements is shown in Figure 6.

In accordance with the idea presented in chapter 2 a calculation model RO has been developed with inserted straight articulated supports at the locations of the designed vibration isolation, as shown in Figure 7.

On the basis of the obtained results, the following assumptions were adopted for further calculations:

- due to the relatively low snow load response values, it will not be taken into account in the next iterations;

- as the dimensioning combination, a combination taking into account all permanent loads and $40 \%$ of variable loads has been assumed.

The elastic modulus of the flexible supports, which are to represent the vibro-insulating material, was determined from the following formula:

$$
\mathrm{k}=\mathrm{F} / \mathrm{d}
$$

where:

$\mathrm{k}$ - support elasticity factor modulus [kN/m],

$\mathrm{F}$ - reaction force $[\mathrm{kN}]$

$\mathrm{d}$ - relative displacement [m].

The maximum value of relative displacement was assumed to be $\mathrm{d}=0.01 \mathrm{~m}$ [18].

The reaction values at the individual nodes corresponding to the columns and the averaged values for the individual walls, as well as the values of the pre-adopted

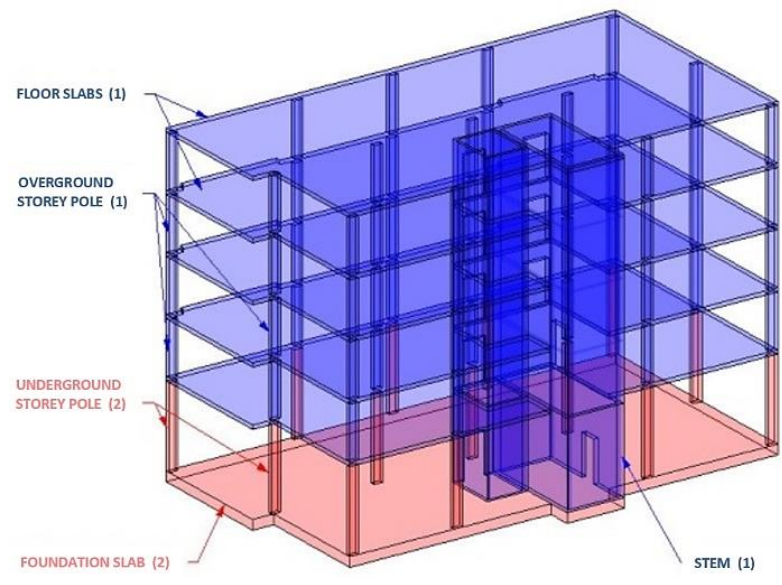

1- insulated elements, 2 - non-insulated elements

Fig. 5. Spatial model of the structure of the designed building 


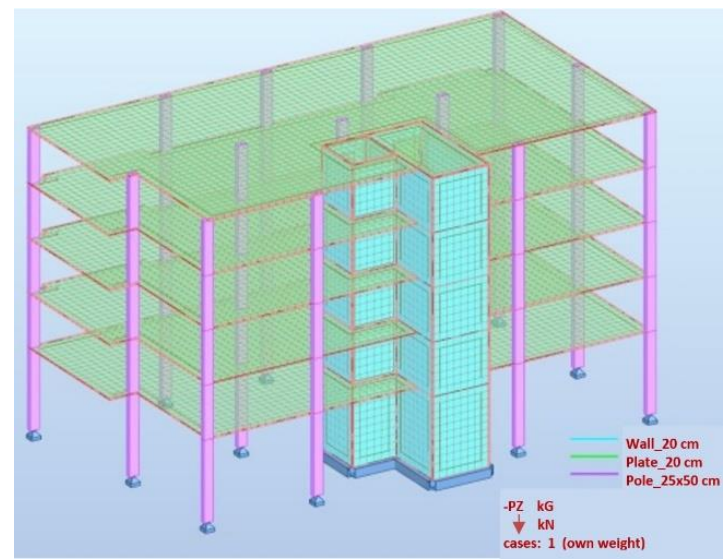

Fig. 6. Basic calculation model of the designed building

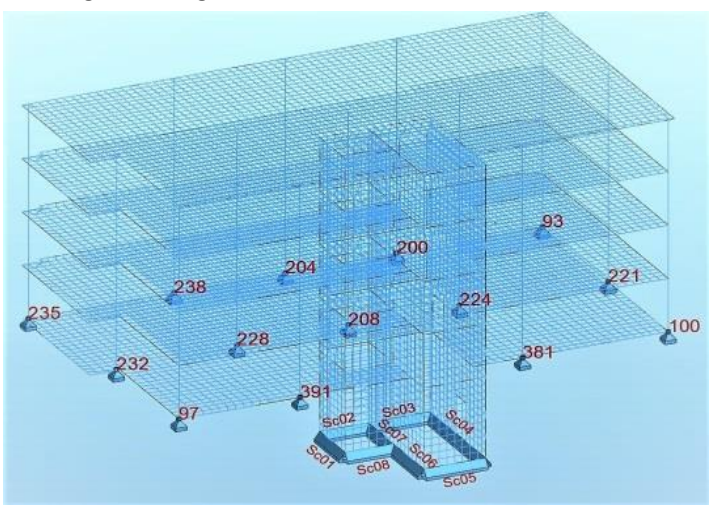

Fig. 7. Calculation model R0 with inserted articulated supports at the vibration isolation sites, with plotted node numbers

elasticity factors of the supports, are shown in Table 1 below. Then, instead of the articulated supports, elastic supports were inserted into the design model of R1 as shown in Figure 8 with the elasticity factors according to the results shown in Table 1. The lateral stiffness of the vibration isolation was not taken into account in further calculations, because for elastomer washers it is negligible (0.5-1.0\%) [14]

As a result of the changed elasticity of the supports, the reaction values at individual nodes have changed. On their basis, in the same way as before, the elasticity of the supports was determined, and updated in the design model. This operation was repeated in subsequent iterations until the difference between the results of individual iterations was not more than approx. $10 \%$. This required a total of fifteen iterations in computational models from R1 to R15.

The values of elasticity factors adopted in the following computational models are presented in the following diagrams shown in Figures 9 and 10.

From the presented results of calculations it is clear that for most of the point (column) and linear (body walls) supports, the elasticity factor values stabilized already at the fourth iteration. Only for point supports around the body (nodes 208, 228, 224, 381 and 391) a further decrease in the value of the reaction and, consequently, in the assumed stiffness of the supports at these points was noted. At the same time, the values of loads taken over by the body walls closest to these pillars increased (mainly supports of Sc03 and Sc07). The effect of higher loads being absorbed by elements with higher stiffness, often found in static calculations of buildings, especially those with a reinforced concrete structure in a cracking state, has been additionally reinforced here by the introduction of spring-loaded supports. The differences between the reaction values of the assumed combination of permanent and variable loads between the initial model RO with straight joints and the same reactions in the final model R15 are presented in Table 2 The results show that the application of vibration isolation between structural elements results in large changes in the values of the transferred loads, which will have a significant impact not only on the final selection of insulating elements, but also on the dimensioning of structural elements under the vibration isolation (underground condition pillars and foundation slab under the walls of the body). 
Causes and methods of applying building protection from the impact of rail-transport

\begin{tabular}{|c|c|c|c|c|c|}
\hline \multirow[b]{2}{*}{$\begin{array}{c}\text { NODE } \\
\text { NUMBER }\end{array}$} & \multicolumn{3}{|c|}{ VALUE OF REACTION DEPENDING ON THE LOAD [kN] } & \multirow[b]{2}{*}{$\begin{array}{c}\text { COMBINATION } \\
1,0 \times \text { CONSTANT+0,4xVARIABLES } \\
{[\mathrm{kN}]}\end{array}$} & \multirow{2}{*}{$\begin{array}{c}\text { ADJUSTED } \\
\text { SUPPORT } \\
\text { STIFFNESS } \\
\text { k2=F/d } \\
{[\mathrm{kN} / \mathrm{m}]}\end{array}$} \\
\hline & $\begin{array}{l}\text { CONSTANT } \\
\text { LOAD - OWN } \\
\text { WEIGHT } \\
{[\mathrm{kN}]}\end{array}$ & $\begin{array}{c}\text { PERMANENT } \\
\text { LOAD - OTHERS } \\
{[\mathrm{kN}]}\end{array}$ & $\begin{array}{l}\text { VARIABLE } \\
\text { OPERATIONAL } \\
\text { LOAD } \\
\text { [kN] }\end{array}$ & & \\
\hline 93 & 308 & 137 & 95 & 483 & 48300 \\
\hline 97 & 210 & 87 & 60 & 321 & 32100 \\
\hline 100 & 257 & 107 & 74 & 394 & 39400 \\
\hline 200 & 554 & 257 & 180 & 883 & 88300 \\
\hline 204 & 402 & 184 & 128 & 637 & 63800 \\
\hline 208 & 506 & 204 & 143 & 767 & 76800 \\
\hline 221 & 640 & 294 & 204 & 1016 & 101600 \\
\hline 224 & 1041 & 460 & 324 & 1631 & 163100 \\
\hline 228 & 937 & 421 & 295 & 1476 & 147600 \\
\hline 232 & 673 & 311 & 218 & 1071 & 107200 \\
\hline 235 & 331 & 149 & 105 & 522 & 52200 \\
\hline 238 & 540 & 250 & 175 & 860 & 86000 \\
\hline 381 & 277 & 88 & 61 & 389 & 39000 \\
\hline 391 & 258 & 92 & 64 & 376 & 37600 \\
\hline \multicolumn{6}{|c|}{ WALL NUMBER } \\
\hline Sc01 & 175 & 44 & 31 & 231 & 23200 \\
\hline $\mathrm{Sc02}$ & 85 & 26 & 18 & 118 & 11900 \\
\hline $\mathrm{Sc03}$ & 180 & 54 & 37 & 249 & 24900 \\
\hline Sc04 & 95 & 18 & 13 & 118 & 11900 \\
\hline Sc05 & 84 & 3 & 2 & 88 & 8800 \\
\hline Sc06 & 102 & 12 & 8 & 117 & 11800 \\
\hline Sc07 & 159 & 40 & 28 & 210 & 21100 \\
\hline Sc08 & 142 & 28 & 19 & 178 & 17800 \\
\hline
\end{tabular}

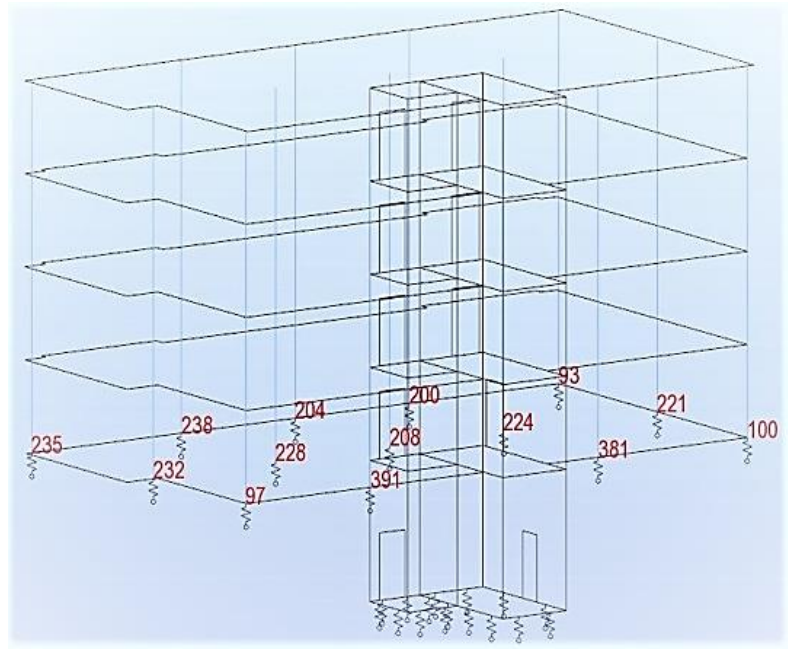

Fig. 8. Computational model of R1 with the introduced spring-loaded supports at the vibration isolation points

Based on the determined results of the R15 reaction shown in Table 2, the elements of vibration isolation in the form of squared elastomer pads with compressive strength of $\mathrm{S}=10 \mathrm{MPa}$ were initially adopted [16]. The minimum surface area $A$ of the subfloor from the formula was determined:

$$
A=R 15 / S
$$

where:

A - min surface area of elastomer pad [m2],

$\mathrm{R} 15$ - response value from Table 2 [kN],

$\mathrm{S}$ - compression resistance of the washer $[\mathrm{kPa}]$. 


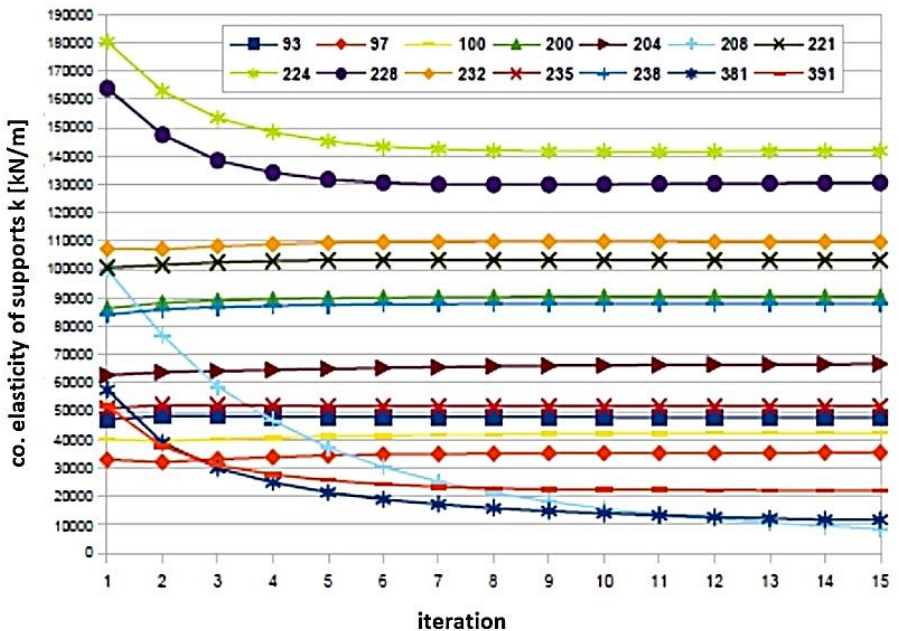

Fig. 9. Chart of elastic modulus change in subsequent iterations for point supports (columns)

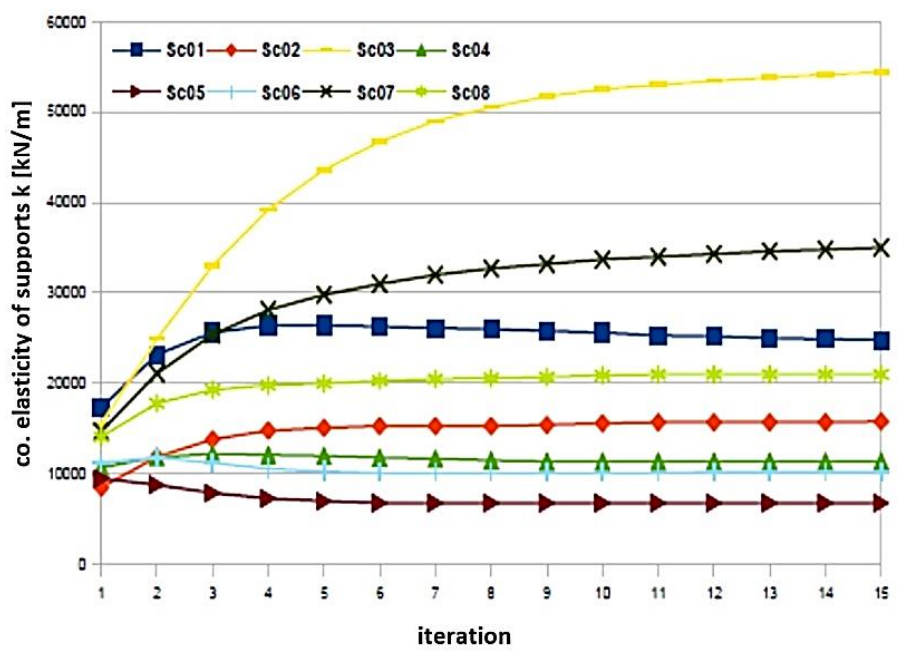

Fig. 10. Chart of elastic modulus change in subsequent iterations for linear supports (body walls)

Taking into account the fact that the designed columns have a rectangular cross-section, the same shape of the designed sub-frames, for which the minimum size will be $0.25 \mathrm{~m}$ [15], was also adopted. On this basis, it was initially assumed that the width of the pad would be $0.25 \mathrm{~m}$, while its length (d) would be equal to the greater of the two values: $0.25 \mathrm{~m}$ and the area $(\mathrm{A})$ divided by $0.25 \mathrm{~m}$ and rounded to the nearest $0.1 \mathrm{~m}$.

For the designed building, a preliminary analysis its natural vibration frequency was also carried out for RO computational model (without the introduced vibroinsulation with hinged supports) and the final R15 model (with elastic supports), in which additional lateral stiffness of elastic supports under the walls of the body with values equal to longitudinal stiffness was assumed.

The analysis was carried out for three cases of load combinations mapping the three stages of building construction [10]:

1) a building with a permanent load but without loads resulting from the finishing (weight of the structural elements only),

2) completed building (with loads resulting from the finishing) but without variable loads,

3) finished building, loaded with constant load together with a reduction of variable load to $40 \%$.

A comparison of the results for the first three natura frequencies is shown in Table 3. 
Table 2. Comparison of the reaction values from the dimensioning combination in the initial model RO and in the final model of R15

\begin{tabular}{|c|c|c|c|}
\hline \multirow{3}{*}{$\begin{array}{l}\text { Node } \\
\text { No. }\end{array}$} & \multirow{2}{*}{\multicolumn{2}{|c|}{$\begin{array}{c}\text { REACTIONS FROM A } \\
\text { COMBINATION DIMENSING } \\
\mathrm{R=1,0} \times \begin{array}{l}\text { permanent load }+0,4 \times \\
\text { variable load }\end{array}\end{array}$}} & \multirow{3}{*}{$\begin{array}{c}\text { RELATIVE } \\
\text { INCREASE OF } \\
\text { THE REACTION } \\
\text { (R15-R0)/R0 } \\
\text { [\%] }\end{array}$} \\
\hline & & & \\
\hline & $\begin{array}{c}\mathrm{RO} \\
{[\mathrm{kN}]}\end{array}$ & $\begin{array}{l}\text { R15 } \\
{[k N]}\end{array}$ & \\
\hline 93 & 470 & 478 & $1,5 \%$ \\
\hline 97 & 328 & 353 & $7,6 \%$ \\
\hline 100 & 401 & 423 & $5,5 \%$ \\
\hline 200 & 863 & 904 & $4,8 \%$ \\
\hline 204 & 626 & 668 & $6,7 \%$ \\
\hline 208 & 1000 & 76 & $-92,4 \%$ \\
\hline 221 & 1007 & 1034 & $2,7 \%$ \\
\hline 224 & 1804 & 1419 & $-21,4 \%$ \\
\hline 228 & 1640 & 1308 & $-20,2 \%$ \\
\hline 232 & 1072 & 1096 & $2,2 \%$ \\
\hline 235 & 510 & 517 & $1,3 \%$ \\
\hline 238 & 841 & 880 & $4,6 \%$ \\
\hline 381 & 576 & 113 & $-80,3 \%$ \\
\hline 391 & 517 & 219 & $-57,6 \%$ \\
\hline wall $n$ & mber. & & \\
\hline Sc01 & 172 & 248 & $44,0 \%$ \\
\hline Sc02 & 85 & 157 & $86,1 \%$ \\
\hline Sc03 & 155 & 543 & $250,5 \%$ \\
\hline Sc04 & 107 & 114 & $6,6 \%$ \\
\hline Sc05 & 94 & 67 & $-28,6 \%$ \\
\hline Sc06 & 112 & 102 & $-9,4 \%$ \\
\hline Sc07 & 146 & 349 & $138,9 \%$ \\
\hline Sc08 & 141 & 210 & $49,0 \%$ \\
\hline
\end{tabular}

Table 3. Frequencies of natural vibrations for models R0 and R15

\begin{tabular}{|c|c|c|c|c|}
\hline \multirow[t]{2}{*}{ COMBINATION No. } & \multirow[t]{2}{*}{ MODEL } & \multicolumn{3}{|c|}{$\begin{array}{c}\text { FREQUENCY } \\
\text { OF OWN } \\
\text { VIBRATIONS } \\
{[\mathrm{Hz}]}\end{array}$} \\
\hline & & f1 & f2 & f3 \\
\hline \multirow{2}{*}{ 1) 1,0 x Own weight } & Ro & 7,04 & 7,24 & 7,37 \\
\hline & R15 & 1,12 & 1,17 & 1,65 \\
\hline \multirow{2}{*}{$\begin{array}{l}\text { 2) } 1,0 \times \text { Own weight }+1,0 \times \text { permanent } \\
\text { load }\end{array}$} & RO & 5,79 & 5,89 & 6,02 \\
\hline & R15 & 0,94 & 1,00 & 1,41 \\
\hline \multirow{2}{*}{$\begin{array}{l}\text { 3) 1,0xOwn weight }+1,0 x p e r m a n e n t \\
\text { load }+0,4 \text { xvariable load }\end{array}$} & Ro & 5,53 & 5,60 & 5,72 \\
\hline & R15 & 0,91 & 0,97 & 1,35 \\
\hline
\end{tabular}

The obtained results show a clear decrease in the value of the building's natural vibration frequency after the introduction of vibration isolation, which may affect both the final selection of the insulation, and the values of assumed wind loads to be accepted for calculations, in particular with respect to tall buildings [20]. In order to improve the dynamic characteristics of the building, it would be advisable to analyse the necessity of implementing additional stiffening elements, taking into account their impact on the static work patterns of structural elements, and the effectiveness of the vibration isolation system [15].

Knowing the dimensions of the washers, it is possible to determine the minimum dimensions of the column heads on which the insulators will be placed. It is necessary to take into account the change in the surface of the washers due to its transverse deformation in both directions under load - initially it is possible to assume the expansion of both head dimensions by approx. $2 \times 10 \mathrm{~mm}$. Next, horizontal loads should be applied to the model and, if necessary, the system of additional post-gravel stiffeners of the building structure and their vibration isolation should be corrected. On the basis of the results obtained, the dimensional calculations for the elements below the line of the introduced acoustic insulation (columns, walls of shafts and their foundations) should be updated. Due to the low transverse stiffness of the washers, it will be necessary to consider, first of all, the change in the static scheme of operation of the columns on which the washers are located, from double-sided mounting to cantilevering. Alternatively, special shear key (Fig. 11) can be used. However, it should be borne in mind that the introduction of excessive number of transverse stiffeners reduces the effectiveness of the vibration isolation system [15].

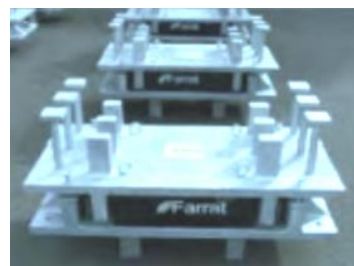

Fig. 11. Shear key module for columns [15]

It should also be noted that in case of end columns, the increased dimension of the heads in relation to the dimensions of the columns will result in an additional force eccentricity (Fig. 12), which may also have a significant effect on the dimensions of the columns and their heads on which the washers are located.

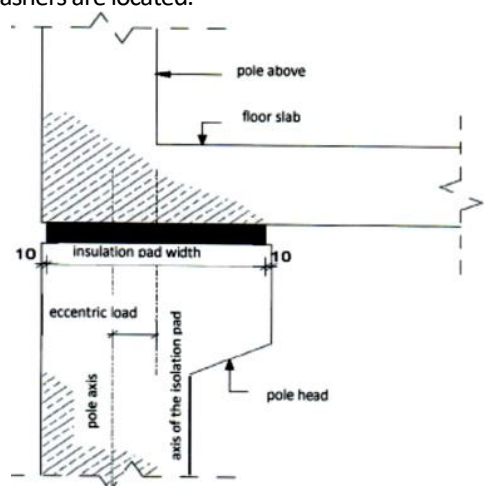

Fig. 12. Additional eccentricity of force for end columns with enlarged heads

The results of the calculations and the resulting changes in the geometry should be confirmed with the acoustician designing the final vibration isolation system and coordinated with the architecture designer, as they can have a significant impact on the layout of the designed surface. In extreme cases, changes, e.g. in the column geometry, may be so important that it will be necessary to redesign part of the building's structural system (shift of columns or walls) or to change basic assumptions about ducting arrangement of the implemented insulation (e.g. isolation of columns at the 
level of the foundations instead of the floor level). In this case it will be necessary to carry out the entire analysis again It should also be remembered that the final design of the vibration isolation and its impact on the building structure will only be possible at the stage when all the additional loads and their arrangement (especially the constant loads from architectural finishing elements) are not changed.

\section{Conclusions}

Due to the increasing demand for collision-free public transport systems in urban agglomerations, the expansion of city centres in the immediate vicinity of above-ground, and sub-surface rail transport, as well as the increasing lega and user requirements for noise reduction in buildings in use, much attention is being paid to reducing the sound leve of this type of transport. At the same time, with the increasing effectiveness of acoustic insulation against airborne noise, more and more attention is also paid to reducing noise from material sounds transmitted through the ground to the building structure, in particular from underground rail transport. One of the methods of isolating buildings from this type of noise is the implementation of a vibro-insulation system in the building structure Consideration of this type of insulation is a complex task requiring cooperation of both acoustician and other participants of the design process. It may also force the necessity to introduce many significant changes in the design of the building, and also significantly affect the costs of its construction. Therefore, the analysis related to the implementation of such a solution should be carried out at the earliest possible stage of the design process. This paper presents a methodology for taking into account the vibration isolation from rail transport in the building structure, which can be applied even at the early stages of the project. The calculation example also shows the impact of its implementation on the calculation and design of the building structure, and outlines further steps to be taken in the subsequent design phases.

\section{PRZYCZYNY I METODY STOSOWANIA OCHRONY BUDYNKÓW} OD WPEYWU TRANSPORTU SZYNOWEGO

W pracy przedstawiono próbę ujednolicenia zagadnienia wibroizolacj akustycznej stosowanej przy projektowaniu budynków i jej wpływ na konstrukcję budynku w oparciu o przykład obliczeniowy. O ile metodologia doboru i sposoby izolacii akustycznej budynków od hałasów komunikacyjnego przenoszonego przez powietrze, jak też metody ograniczenia drgań konstrukcji do dopuszczalnych poziomów są powszechnie rozpoznane i stosowane, brak jest natomiast ogólnie przyjętej metodyki ograniczenia wtómego hałasu, który może powstawaćwbudynkach wskutekdrgań przenoszonych poprzezgnunt na fundamenty i konstrukcję budynku ( $t z w$. drgania materiałowe, ang. ground-bomenoise lub re-radiated noise)

Słowa kluczowe: drgania, wibroizolacja, dźwiękoizolacja, drgania materiałowe

\section{BIBLIOGRAPHY}

[1] Engel Z., Panuszka R. (1989) Podstawyakustyki, Wyd. AGH, Kraków

[2] Sadowski J. (1971) Akustyka w urbanistyce, architekturze i budownictwie, Wyd. Arkady, Warszawa
[3] Kisilowski J., Strzyżakowski Z., Woroszył S. (1985) „Metoda modelowania zjawisk dynamicznych układu mechanicznego pojazd-tor-otoczenie", Archiwum Inżynierii Lądowej, tom XXXI

[4] Univeristy of Southampton, Ground Vibration and Ground Borne Noise from Trains, https://www.southampton c.uk/engineering/research/groups/dynamics/rail/ground_vibra tion.page [access: October 2018]

[5] Rozporządzenie Ministra Infrastruktury z dnia 12 kwietnia 2002 r. w sprawie warunków technicznych, jakim powinny odpowiadać budynki i ich usytuowanie, Dz.U. 2002 nr 75 poz. 690 z późn. zmianami

[6] PN-B-02151-2:2018-1 Akustyka budowlana - Ochrona przed hałasem w budynkach. Część 2: Wymagania dotyczące dopuszczalnego poziomu dźwięku w pomieszczeniach

[7] Arup, Impacts of Tunnels in the UK, 01 June 2015, http://chelsea4crossrail2.co.uk/wp-content/uploads/2015/12/ Impacts-of-Tunnels-in-the-UK-Arup.pdf [access: October 2018]

[8] MTR Corporation Limited, West Island Line Environmental Impact Assessment, October 2008, https://www.epd.gov.hk/ eia/register/report/eiareport/eia_1532008/EIA-pdf/S4.pdf [access: October 2018]

[9] California Department of Transportation (Caltrans), Los Angeles County Metropolitan Transportation Authority (Metro), SR 710 North Study. Groundborne Noise and Vibration Impacts, November 2014, http://www.dot.ca.gov/dist07/resources/env docs/docs/710study/draft eireis/Groundborne\%20Noise\%20 nd\%20Vibration\%2OImpacts/SR\%20710\%20Groundborne\%20 Noise\%20Vibration\%2Olmpacts.pdf [access: October 2018]

[10] PN-B-02170:2016-12+Ap1/2017-10 Ocena szkodliwości drgan przekazywanych przez podłoże na budynk

[11] PN-B-02171:2017-06 Ocena wpływu drgań na ludzi w budynkach

[12] Targosz J. (2013) Wibroizolacja torowisk tramwajowych Logistyka 3/2014, pp. 6296-6303

[13] Stecz P. (2014) Wpływ działania na budynki długotrwałych obciążeń dynamicznych generowanych przejazdami pociągów metra. Rozprawa doktorska, Kraków 2014, Biblioteka Cyfrowa Pol. Krakowskiej, https://suw. biblos. pk. edu. pl/ resources /i4/i7/i2/i2/i0 /r47 220/ Stecz P.Wpływ Dzialania.pdf [access: October 2018]

[14] Farrat VCAS-DG-Buidling Vibration Isolation-17a. Building Vibration Isolation Systems. Vibration control for building andstructures, www.farrat.com/wp-ntent/uploads/2017/11 /VCAS-DG-Building-Vibration-Isolation-17a-WEB.pdf, [access: October 2018]

[15] Mason Industries Inc, https://mason-ind.com/spring-isolators/ [access: October 2018]

[16] Davis D. (2010) „A Review of Prediction Methods for GroundBorne Noise due to Construction Acitivities", Proceedings of 20th International Congress in Acoustics, ICA 2010, Sierpien 2010, Sydney, Australia

[17] PN-EN 1992-1-1:2008 Eurokod 2. Projektowanie konstrukcji z betonu. Część 1-1: Reguły ogólne i reguły dla budynków, wraz z Załącznikiem Krajowym PN-EN 1992-1-1:2008/NA:2016-11

[18] PN-EN 1997-1:2008 Eurokod 7. Projektowanie geotechniczne. Część 1: Zasady ogólne, wraz z Załącznikiem Krajowym PN-EN 1997-1:2008/NA październik 2011

[19] PN-EN 1991-1-4:2008 Eurokod 1. Oddziaływania na konstrukcje. Część 1-4: Oddziaływania ogólne. Oddziaływania wiatru, wraz z Załącznikiem Krajowym PN-EN 1991-1-4: 2008/NA wrzesień 2010

[20] website: www.tines.pl

[21] website: www.calenberg-ingenieure.com

[22] website: Farrat-DG-building vibration isolation-17a, www.farrat com/wp-content/uploads/2017/11, [access: October 2018]

[23] https://mason-ind.com/spring-isolators [access: October 2018] 